\title{
СОЦИЈАЛНА НЕЈЕДНАКОСТ У РУСКИМ И СРПСКИМ ПАРЕМИЈАМА: ЛИНГВОКОГНИТИВНА АНАЛИЗА*
}

Овај рад садржи анализу руских и српских паремија које одражавају социјалну раслојеност руског и српског друштва. Главни задатак је анализа паремиолошког поља концепата који чине социјалну пирамиду на чијем се врху налази цар, а испод њега налазе се различити представници више, средње и ниже класе. Истраживање је извршено на основу лексикографког материјала у оквиру семантичко-когнитивног метода J. А. Стерњина. Резултати истраживања представљају детаљан опис паремиолошких поља наведених концепата, која су упоређена са напоредо анализираним српским паремиолошким пољима. Приликом анализе паремиолошких поља, која се посматрају као важни делови концепата издвојена су најфреквентнија когнитивна обележја на основу којих се закључује о позитивном или негативном односу народа према представницима одређеног сталежа.

Кључне речи: социјални концепт, когнитивна анализа, социјална неједнакост, паремиологија, руски језик, српски језик.

The purpose of this paper is to present the analysis of proverbs that reflect social stratification in Russian and Serbian society. The objective of this study is to research concepts referring to members of the social pyramid with the king at the top, and other various representatives of high, medium or low-social status members of society at the bottom of the pyramid, as they are represented in the Russian and Serbian proverbs. The research is based on lexicographic and paremiological material, using J. A. Sternin semantic-cognitive methodology. We have presented a detailed description of paremiological fields of the mentioned concepts and compared it to the equivalent Serbian material. During the process of semantic analysis, we isolated the most frequent cognitive characteristics for all the mentioned concepts and paid special attention to the positive or negative attitude of society towards the various representatives of different social strata.

Key words: social concept, cognitive analysis, social inequality, paremiology, Russian language, Serbian language.

У овом раду извршена је лингвокогнитивна анализа паремиолошког поља социјалних концепата који одражавају социјалну неједнакост припадника ниже, средње и више класе двају народа. Пронађено је укупно 400 паремија 338 руских и 62 српске пословице. Пословице су анализиране у оквиру паремиолошких поља следећих социјалних концепата: представник власти, представник цркве, представник вишег сталежа, представник нижег сталежа. Због ограниченог обима у раду су представљени само закључци и наведени су најрепрезентативнији примери.

* Овај рад представља део мастер рада са темом „Социјална неједнакост у руским и српским паремијама: лингвокогнитивна анализа“, насталог под менторством проф. др Марије Стефановић, одбрањеног 17.01.2019. на Филозофском факултету у Новом Саду. 


\section{Представник власти}

Након покрштавања Русије у 10. веку хришћански религијски култ подстицао је морално-религиозне идеале руског народа. Руска земља постепено је почела да се у свести народа поистовећује са оваплоћењем Светог Духа, добивши назив Света Русија (Кондаков 2003). Такво потчињавање релативног света (политичког и друштвеног) свету апсолутном (религиозном) подстицало је руски народ да за политичким идеалима трага под Божјим покровитељством, што је значило да вођа мора имати монархистичку власт потчињену Богу (Тихомиров 2008). Монарх није био само помазаник Божји, већ и живо оваплоћење Бога на земљи - пандан Небеском цару (Кондаков 2003).

У руском паремиолошком фонду који описује концепт представник власти пронађено је укупно 66 пословица које садрже следеће номинаторе: царь, государь, князь. Доминантна лексема у оквиру овог концепта је лексема царь. Све пословице поделили смо у 3 групе. Највећи број паремија припада групи цар - Бог $(50 \%)$, на основу које су издвојена најважнија когнитивна обележја овог концепта: 1) Цар је (једини) владар на земљи, а Бог - на небу (Бог на небе, иарь на земле); 2) Цар је судија на земљи, али није изнад Божјег закона (Царь от бога пристав); 3) Цара треба поштовати (Бога бойся, а царя почитай); 4) Пред царем су сви равни (Бог бескровен, царь безроден).

Групи цар - народ припада $33 \%$ пословица. У оквиру ове групе издвојене су следеће когнитивне особине цара: 1) Цар је вођа народа (Народ - тело, иарь - голова; Царь думает, а народ ведает); 2) Цар има највишу власт на земљи (Не Москва государю указ, государь Москве; Воля ичаря - закон); 3) Цар је судија (Царю правда - лучший слуга; Где иарь, тут и правда (и страх, и гроза)); 4) Цар је заштитник (Царь города бережет); 5) Цар гради градове (Царь государь и городы платит (т.е. чинит)); 6) Цар је један од услова постојања земље (Нельзя быть земле русской без государя; Без ияаря - земля вдова).

Однос цар - слуге садржи најмањи број пословица - 17\%. На основу овог односа издвојена су 4 когнитивна обележја: 1) Цару су потребне слуге ( Царь без слуг, как без рук); 2) Цар не може угодити свима (Ни солнышку на всех не угреть, ни изарю на всех не угодить); 3) Цар није свеприсутан (Царю из-за тына не видать); 4) Цар је окружен људима који у његово име народу наносе неправду (Не от иарей угнетение, а от любимиев царских). У свести народа владар је кључна фигура у свакој земљи, од њега је само Бог већи и због тога цар мора бити праведан и милостив према народу који предводи, да му праведно суди и штити га. Дакле, добар цар темељ је сваке земље. Али, цар не може да угоди свима. Са врха пирамиде он не види шта се на дну дешава и због тога многе његове непосредне слуге и блиски сарадници (љубимци, чувари паса, особе које иду у потеру итд.) преузимају на себе важност коју има цар, па их се поданици (обични људи без веза са царем) боје.

У српском паремиолошком фонду пронађено је само 12 пословица, од којих 8 садржи лексему цар, 2 - лексему кнез, док су са одредницом краљь и господар пронађене само две пословице. Дакле, и у српским пословицама доминатна је лексема цар, а основна когнитивна обележја су: 1) Владар је на земљи Бог на небу (Бог на небу, а изар на земљи, Бог високо, а иар далеко); 2) Владар није 
изнад Бога (Старија је Божја но изарева); 3) Владар узима харач (Бог дао а цзар нема шта узети); 4) Владар је милостив (Бог гријехове, а изар дугове); 5) Владар заповеда ( $У$ тућој кући кнез, а у својој јеж); 6) Владар је изнад народа (Зар ће и кнез с нама ручати? Рекао ичиганин харачлији, кад се и кнез пред ручак умивао; а харачлија му одговорио: „Хоће кнез ал нећеш ти“); 6) Од владара се не очекује добро (Тешко ономе кога цуар каје); 7) Народ се не боји владара (И мачка је краљь гледала ама га се није бојала).

И у руској и у српској језичкој слици света представа о цару перципира се најпре кроз његов однос према Богу. У пословицама је очигледна подела власти и утицаја коју имају Бог и цар - Бог се везује за вертикалну сферу и небо, док се цар везује за хоризонталну сферу и земљу и његова власт ограничена је неприкосновеном Божјом вољом. Док се у руским пословицама открива изразито позитиван однос према цару, српске пословице карактерише негативна тоналност и критички однос према цару као врховном владару.

\section{Представник цркве}

У оба језика пронађен је највећи број пословица које описују концепт представника цркве. У руском паремиолошком фонду пронађено је 107, а у српском - 34 пословице.

Све руске пословице поделили смо у 4 групе. Групи поп - црква припада $28 \%$ пословица које говоре о хијерархијској подели представника цркве, али и о њиховим дужностима. На врху хијерархијске лествице је архијереј, затим свештеник, а најнижи чин припада ђаконима и звонарима (Из попов да в дьяконьл; Попу кунииу, дьяконулисииу, пономарю серого зайку, а просвирне-хлопуше - заячьи уши). Дужности описане у паремијама односе се само на свештеника. На основу пронађених паремија можемо издвојити следећа когнитивна обележја: 1) Поп врши службу у цркви (Поп поет, кузнец кует, солдат свою службу несёт); 2) Поп крсти (Безумный поп тебя крестил - дурак, что не потопил); 3 ) Поп сахрањује (Om попа не уйдешь: похоронит; Ждучи поп усопиих, да и сам уснул); 4) Поп венчава (Плохой поп свенчает, и хорошему не развенчать); 5) Поп освештава (Нечего годить когда поп кадит; Кадило, кадило и попу привалило); 6) Попу се иде на исповест (Наш грех стьдно и попу сказать; К сонному попу на исповедь не ходят); 7) Поп не брине о цркви (Три попа, а заросла в цеерковь тропа).

Групи социјални и породични статус свештенослужитеља припада само $11 \%$ пронађених паремија, које описују препознатљив начин одевања попа (Если не поп, не суйся в ризы), његов однос према попадији (Бережет, что поп попадью), као и материјални статус (Лучше жить в попех нежели в холопех).

Категорији поп - ђаво припада најмањи број пословица (9\%) и по својој структури веома су противуречне. У неколико пословица прави се паралела између попа и ђавола, тј. поистовећују се, док се у осталим пословицама може приметити њихов опозициони однос. Овакво поређење попа и ђавола вероватно је настало због застрашивања народа нечистим силама.

Највећи број паремија о представнику цркве припада групи поп - народ (50\%), а доминатна обележја у оквиру ове групе су: 1) Поп наплаћује своје ус- 
луге (Родись, крестись, женись, помирай - за все попу деньги давай); 2) Попу припада део летине (Не отсыпав попу новины, хлеба не продавай); 3) Поп је прождрљив (Попа одним обедом не накормишь); 4) Поп је похлепан (Вольчя пасть да поповские глаза - ненасытная яма); 5) Поп је завидљив (Не бери у попа денег взаймы: : $у$ завистливого рука тяжела); 6) Поп је преварант (Безмен не попова душа, не обманет); 7) Поп је необразован (Уела попа грамотка); 8) Поп је грешан (Стоит ад попами, дьяками да неправедными судьями); 9) Поп је неопходан (Без попа, что без соли. Без попа не приход). Из горенаведеног можемо закључити да је однос народа према црквенослужитељима негативан, те се истима приписују негативне особине. Ипак, поред свих лоших особина попа, народ је свестан неопходности постојања свештеника у селу.

Српске пословице подељене су у 3 групе, а највећи број пословица припада групи поп - народ (49\%). Српски свештеници су, као и руски, живели од прихода који сакупе од народа. Народ је тај приход давао најчешће у виду хране, иако је свештеницима (како сазнајемо из пословица) био дражи новац. У оквиру овог односа издвојили смо следеће когнитивне особине: 1) Поп наплаћује своје услуге (Срдиту nопу празне бисаге); 2) Неопходност постојања попа (Ако ће триста, без попа ништа); 3) Поп је сит (Најми се ти у мене а ја ћу у попа, y попа је боља храна); 4) Поп је расејан (Поп кобилу јаше, а кобилу тражи) ; 5) Поп је мудар (У попа би ваљьло да су и прасад мудра; а у њега су и ђеиа луда); 5) Поп је беспослен (Беспослен поп и јариће крсти); 6) Поп је похлепан (Поповска врећа никад се напунити не може); 7) Поп је опасан (Поповска свађа, ђаволска свадба).

Групи поп - црква припада $46 \%$ пословица. Када говоримо о обавезама свештенослужитеља у фокусу српских пословица је најпре делатност обраћања народу кроз богослужбене књиге. Од Светих тајни које обавља свештеник наглашава се само обред покајања, тј. исповести. На основу пронађених пословица можемо издвојити следеће когнитивне особине овог концепта: 1) Поп проповеда (Не гледај ито поп твори, него слушај ито збори; Турии силом, а калућери књигом поћераше нас у сиромаштво; Добар поп до смрти се учи); 2) Поп исповеда (Говори, за попом говорио! - болестан на исповјести).

Категорији породични статус попа припадају само две пословице: Нема већег бокиа од попа удовиа; Ко попа, ко попадију (тј. воли). Обе су хумористичког карактера, а прва пословица указује на зависност попове среће од попадије, тј. поп удовац је нужно несрећан човек.

У оба народа створена је представа о похлепном попу који наплаћује своје услуге. Најфреквентнија обележја у руским пословицама су: прождрљивост, порочност, завист, док су у српским доминатне следеће особине: cuтост, расејаност и беспосленост. У руским пословицама о образованом попу говори се подругљивим тоном, у српским, пак, очигледан је делимично позитиван однос према ученом попу (са наглашеним закључком о томе да поп манипулише народом - позивајући се на богослужбене књиге, он оправдава наплаћивање услуга, те народ тера у сиромаштво). У оба језика истакнут је сатиричан однос према свештеницима, који је највише заступљен у пословицама које говоре о поповом односу према храни и према попадији. 


\section{Представник вишег сталежа}

У руском језику пронађене су 94 пословице које описују концепт представник вишег сталежа. У опис овог концепта улазе лексеме боярин, воевода, барин (као и квазисиноними дворянин, господин) што нам даје дијахронијски увид у руску историју од 11. до 19. века. Паремиолошки фонд обухвата период старе Русије у којој су владајућу елиту чинили бољари и војводе и период феудалне Русије у коме су спахије имале власт над народом.

Највећи број пословица односи се на спахије (76\%). Дате пословице поделили смо у две групе. У оквиру групе спахија - сељак издвојили смо следеће особине овог концепта: 1) Спахија не ради физичке послове (Барской работы не переработаешь; Кто барствует, тот и ицарствует); 2) Спахија је опасан, јер даје лажна обећања и није доследан (Барский гнев да барская милость (равно опасны); Барская ласка до порога); 3) Спахија је изнад сељака (Барин за барина, мужик за мужика); 4) Спахија живи у изобиљу (Красны боярские палаты, а у мужиков избы на боку); 5) Спахија је лош (В те поры холопу время, когда господину безвременье; Холоп да брюхо добра не помнят); 6) Спахија је добар (У хорошего барина и дворня хороша;Не станет хлеба, барин даст).

У оквиру групе социјални и материјални статус могу се издвојити само два когнитивна обележја: 1) Спахија је сиромашан и не плаћа дугове ( $У$ нашего господина ни ржи, ни овина; Голь голянский сын дворянский); 2) Спахија је племенитог порекла (Бары крупчатые, да сдобные, а мужики - ржаные, да с закалом; Дворянская кровь и в Петровки мерзнет).

Сељаци су у потпуности зависили од господареве воље. Њихова потпуна зависност огледа се и у томе што су испаштали и онда када нису били криви. Овакво понашање спахија може се објаснити различитим схватањем добра и зла. Сељаци су за спахије били искључиво физичка бића, неопходна за испуњавање многих обавеза. Зато сељаци нису схватали епизодне манифестације господареве милости као нешто устаљено, доследно и поткрепљено истинским моралним начелима (Шаповалов 2012). У пословицама, дакле, можемо уочити и опозициони карактер односа спахија - сељак, у коме се прави јасна разлика између света припадника више и ниже класе. Ту разлику сељаци уочавају на основу материјалног богатства и начина живота спахија. Из горенаведеног може се уочити да су доминантна обележја концепта спахија његове негативне особине (спахија не обавља физичке послове, има власт над сељачима, опасан је) из којих произилази и негативан став сељака према спахијама. Међутим, није занемарљив ни број пословица у којима је очигледан позитиван однос сељака према својим господарима. Разноликост пословица указује на разноликост племићке класе коју су чинили људи разних чинова, различитог материјалног статуса.

Само 14\% пословица описује припаднике више класе средњовековне Русије, тј. бољаре. У пословицама се не описују конкретне спољашње и унутрашње карактеристике овог слоја, већ се бољарске особине сагледавају кроз њихов однос према народу, на основу којег можемо издвојити следеће когнитивна обележја овог концепта: 1) Бољари су немилосрдни (Вселился черт в боярской двор; Неволя, неволя, боярский двор! Ходя наешься, стоя выспишься); 2) Бољари су опасни (С боярами не ешь вишен, а то костьми закидают); 3) Бољари су из- 
над сељака (Боярин шуту рад, да с ним не ходит в ряд); 4) Бољари живе у изобиљу (И мы видали, как бояре едали).

Руски народ, дакле, није оспоравао умне и ратне способности бољара, али с друге стране, знао је да и највиши сталежи зависе од најнижег слоја - сељачког становништва које је радило на имањима: Не грози боярин (барин) холопу хлебом, а холоп боярину бегом (т.е. работой).

Лик војводе описан је кроз најмањи број пословица (10\%) и перципира се искључиво кроз негативне особине као што су властољубље и похлепа: Воевода хоть и не стоит лыка, а почитай его велико; Конь любит овес, а воевода принос. Војводу, притом, нико не контролише и зато је он опасан (На воеводу просить, что в тьюрму идти; Худо овияам, где волк воевода).

У српском језику само 12 пословица улази у опис концепта припадник вишег сталежа, чију структуру чине номинатори господин, бег, ага, спахија. Притом, бег и ага означавају представнике турског племићког сталежа, што нам открива историјску чињеницу о томе да је Србијом дуги низ година владало Османско царство. Доминатна лексема у српским пословицама која описује овај концепт је уопштена лексема господин, док само 5 пословица садржи конкретне лексеме које описују припаднике вишег сталежа - бег, ага и сnахија. На основу пронађених пословица издвојили смо следеће когнитивне особине концепта представника вишег сталежа са одредницом господин: 1) Господа су опасна (С великом господом није добро трешње јести (Играјући се кошчицама, сиромаха ће у очи тући); Господскоме смијеху и ведру небу не ваљь вјеровати, јер се за час промјене); 2) Господи је све дозвољено (Велика господа (само) и пси врата за собом не остављају); 3) Господа живи у изобиљу (Шета се као гладан господин;Изриј као свиња, а изједи као господар (т.j. добро ради, а добро једи)); 4) Господа заповеда (Велике господе молба, по готову заповијест); 5) Господу чини рухо (Храна храбра, а рухо господара чини).

$\boldsymbol{E} \boldsymbol{e z}$ се у Речнику српскохрватскога књижевног језика дефинише као муслимански племић, велепоседник у турском царству. На основу пронађених паремија можемо издвојити следеће категорије:1) Бег има власт: Ако ћу криво, не смијем од Бога, ако ћу право не смијем од бега; 2) Бег живи у изобиљу: Живи као бег на Хериеговини (добро); 3) Бег је човек племенитог порекла (Беговаи је беговач ако неће имати ни новаи; а магараи је магараи, ако ће имати и златан покроваи).

У зборнику српских пословица пронађена је само једна пословица са одредницом ага на основу које можемо издвојити обележје ага има власт (Вежи коња ђе ти ага (господар) заповеда).

Са одредницом сnахија пронађена је, такође, само једна пословица из које се може издвојити обележје: спахија узима порез (Ко нема спахије, нека купи сахат (па ће оправљајући га потрошити оно, што би плаћао спахији)).

У српским пословицама је, дакле, доминантан негативан однос српског народа према племићком сталежу, а као основна обележја истичу се социјални и материјални статус представника више класе. 


\section{Представник нижег сталежа}

У паремиолошком фонду руског језика пронађена је 71 пословица која описује концепт представник нижег сталежа. У опис овог концепта улазе номинатори: мужик, холоп (раб, слуга), смерд. Најфреквентнија је лексема мужик (67\%), а као њена основна обележја истичу се: 1) марљивост (Лень мужика не кормит); 2) простота (Мужик задним умом крепок); 3) порочност (Крестьянин пьян, сам себе пан); 4) тврдоглавост (Мужик, что рогатина; как упрется, так u cmoum). Међусобно противуречне пословице пронађене су у оквиру групе материјални статус сељака (Мужик не богат, а горбат; Мужик богатый гребет деньги лопатой; Мужик богатый что бык рогатый), а многе пословице нам откривају и њихову међусобну неједнакост. Наиме, сељаци су се делили на спахијске и државне сељаке (Не равны бары, не равны и крестьяне). Сељаци који нису припадали спахијама били су слободни, док су спахијски морали да живе онако како им спахија одреди (Казеннылй крестьянин живет, как бог велит, а барский, как барин рассудит). С друге стране, спахијски сељаци су под покровитељством својих власника живели спокојније (Вольному (казенному) просторнее, барскому спокойнее (жить)).

Пословице које садрже лексему холоп (23\%) под робом подразумевају само сиромашног, купљеног роба, чија је најпожељнија особина оданост господару (Неволя холопу, воля господину; Не куплен - не холоп, не закабален-не работник; Верен раб - и господин ему рад).

У пословицама које садрже одредницу смерд (10\%) наглашавају се само негативне особине сељака као што су неинтелигентност, неуредност, страх, непокорност (Где смерд думал, тут Бог не был; Как смерд ни моется, а все смердит; Не смердье дитя, не дрогнет рука; Еловый пень не отродчиво, а смердей сын не покорчиво).

У српском језику пронађене су само 4 пословице са одредницом кмет у значењу „судија/ предводник сељака“, на основу којих можемо издвојити следеће когнитивне особине: 1) Кмет је лош (Куд ће штета те на рђава кме$m a)$; 2) Кмет не промишља пре него што нешто каже (У луда кмета брза бесједа); 3) Кмет је судија (Прица и кмет не може бити); 4) Кмет је сеоски предводник (Да нијеси са мном љетовао не би тако кметовао (Од мене си научио то што знаш)). У овим пословицама приказан је само негативан однос према кметовима.

На основу датог паремиолошког материјала можемо закључити да се највећи број пословица и у руском и у српском језику односи на представнике иркве. Однос народа према црквенослужитељима у оба језика представљен је кроз сатиричан опис њихових негативних особина. Велики број пословица у руском језику описује и представнике вишег сталежа, према којима је руски народ амбивалентан. Сходно томе могу се издвојити противуречна когнитивна обележја као што су добар/лош, богат/ сиромашан. Овакав амбивалентан однос према припадницима вишег сталежа није забележен у српским паремијама. Анализирајући порекло лексема које означавају представнике вишег слоја, можемо закључити да су овај слој чинили људи турског порекла - туђини, те су они у свести српског народа перципирани искључиво кроз њихове негатив- 
не особине. Није занемарљив ни број руских пословица које описују ниже друштвене слојеве и у којима је сељак представљен као прост, порочан, тврдоглав, али и као лукав, рационалан и марљив. У српском паремиолошком фонду, пак, пронађене су само 4 пословице са одредницом кмет, које указују само на његове негативне особине. Мали број српских пословица пронађен је и у оквиру категорије представник власти, а цар се у српској свести перципира као неко ко узима плодове мукотрпног рада сељака и од кога се не може очекивати ништа добро. Насупрот томе, у руским паремијама преовладава само позитиван однос према цару као према врховном владару на земљи, изнад кога је само Бог. Број и разгранатост руских пословица, без обзира на негативан став према владарима, указују да су их видели као „своје“, док су Срби њих видели као туђине од којих се треба удаљавати и чувати.

Српске пословице конкретније су од руских и углавном се односе на особине личности, без упућивања на припадност одређеном сталежу (јер су и настале и забележене сакупљањем унутар једног истог слоја - обесправљеног становништва). Обим двају Зборника (Даљевог и Вуковог) је такође различит, што утиче на укупан број пословица.

Будући да је издвојен мали број пословица на основу којих се не може направити целовит и сврсисходан опис социјалних концепата у српском језику, ово истраживање може се проширити даљом анализом социјалног раслојавања исказаног у народној књижевности.

\section{Цитирана литература}

Кондаков, Игорь В. Культурология. История культуры России. Москва: ОМЕГА-Л, 2003.

Тихомиров, Лев А. Руководящие идеи русской жизни. Москва: Институт русской цивилизации, 2008.

Шаповалов, Владимир А. „Русский помещик в народном фольклоре: благородство и жестокость (социально-психологический аспект)“. Научные ведомости Белгородского государственного университета. Серия: История. Политология, 2012.

https://cyberleninka.ru/article/n/russkiy-pomeschik-v-narodnom-folkloreblagorodstvo-i-zhestokost-sotsialno-psihologicheskiy-aspekt

$* * *$

Zirojević, Olga. Srbija pod turskom vlašću 1459 - 1804. Drugo, pregledano i ilustrovano izdanje. Beograd: Srpski genealoški centar, 2007. 


\title{
Извори
}

Даль, Владимир И. Пословицы русского народа в двух томах. Москва: Художественная литература, 1984.

Даль, Владимир И. Толковый словарь живого великорусского языка. Москва: Русский язык, 1987.

Караџић, Вук С. Српске народне пословице. Београд: Просвета-нолит, 1985.

Кончаревић, Ксенија, Радовановић Милан. Руско-српски и српско-руски теолошки речник. Београд: ЈП Службени гласник, 2012.

Ожегов, Сергей И. Толковый словарь русского языка, 27-ое издание, исправление. Москва: Мир и образование, 2016.

Рыбникова, Мария А. Русские пословицы и поговорки. Москва: Академия наук СCCP, 1961.

Соболев, Антон И. Русские пословицы и поговорки, Москва: Советская Россия, 1983.

Станковић, Богољуб. Руско-српски речник, допуњено издање. Нови Сад: Прометеј, 2009.

Стевановић, Михаило и др. Речник српскохрватскога књижевног језика. Друго фототипско издање, 6 књига. Нови Сад: Матица српска, 1990.

Фасмер, Макс. Этимологический словарь русского языка. Москва: Прогресс, 1987.

Шћепановић, Михаило. Вукове народне пословице са регистром кључних речи. Београд: Јасен, 2015.

\section{Елена Стошич}

\section{СОЦИАЛЬНОЕ НЕРАВЕНСТВО В РУССКИХ И СЕРБСКИХ ПАРЕМИЯХ: ЛИНГВОКОГНИТИВНЫЙ АНАЛИЗ}

\author{
Резюме
}

В работе анализируются русские и сербские паремии, отражающие социалньое неравенство. Рассматриваются социальные концепты и описывается их содержание в форме перечисления выявленных когнитивных признаков. Главная задача работы - анализ паремиологического поля концептов, которые отражают социальную структуру, на вершине которой находится царь, а ниже царя - представители высшего, среднего и низшего сословий. В работе используется метод семантического исследования концептов. В результатах исследования представлено подробное описание паремиологических полей данных концептов.

Проведённый анализ концептов позволяет сделать вывод об отношении народа к представителям определённых сословий.

Ключевые слова: социальный концепт, когнитивный анализ, социальное неравенство, паремиология, русский язык, сербский язык. 